\title{
Laboratory results in ocular viral diseases: implications in clinical-laboratory correlation
}

\author{
Resultados laboratoriais nas doenças virais oculares:implicações na \\ correlaçãoclínico-laboratorial
}

\author{
Fabiana Bogossian Marangon ${ }^{1}$ \\ Darlene Miller ${ }^{2}$ \\ Eduardo Alfonso ${ }^{3}$
}

Trabalho realizado no Bascom Palmer Eye Institute, University of Miami, Florida - EUA.

${ }^{1}$ Oftalmologista, pós-graduanda da Universidade Federal de São Paulo - UNIFESP - São Paulo (SP) - Brasil.

${ }^{2}$ Microbiologista, Universidade de Miami, Bascom Palmer Eye Institute. Miami - EUA.

${ }^{3}$ Professor do departamento de oftalmologia, Universidade de Miami, Bascom Palmer Eye Institute. Miami - EUA.

Endereço para correspondência: Fabiana B. Marangon. R. Tabapuã, 888 - Cj. 45 - São Paulo (SP) CEP 04533-003 E-mail: fbmarangon@yahoo.com.br

Recebido para publicação em 16.03.2006

Última versão recebida em 19.11.2006

Aprovação em 24.11.2006

Nota Editorial: Depois de concluída a análise do artigo sob sigilo editorial e com a anuência do Dr. Sérgio Kwitko sobre a divulgação de seu nome como revisor, agradecemos sua participação neste processo.

\begin{tabular}{|c|}
\hline ABSTRACT \\
\hline 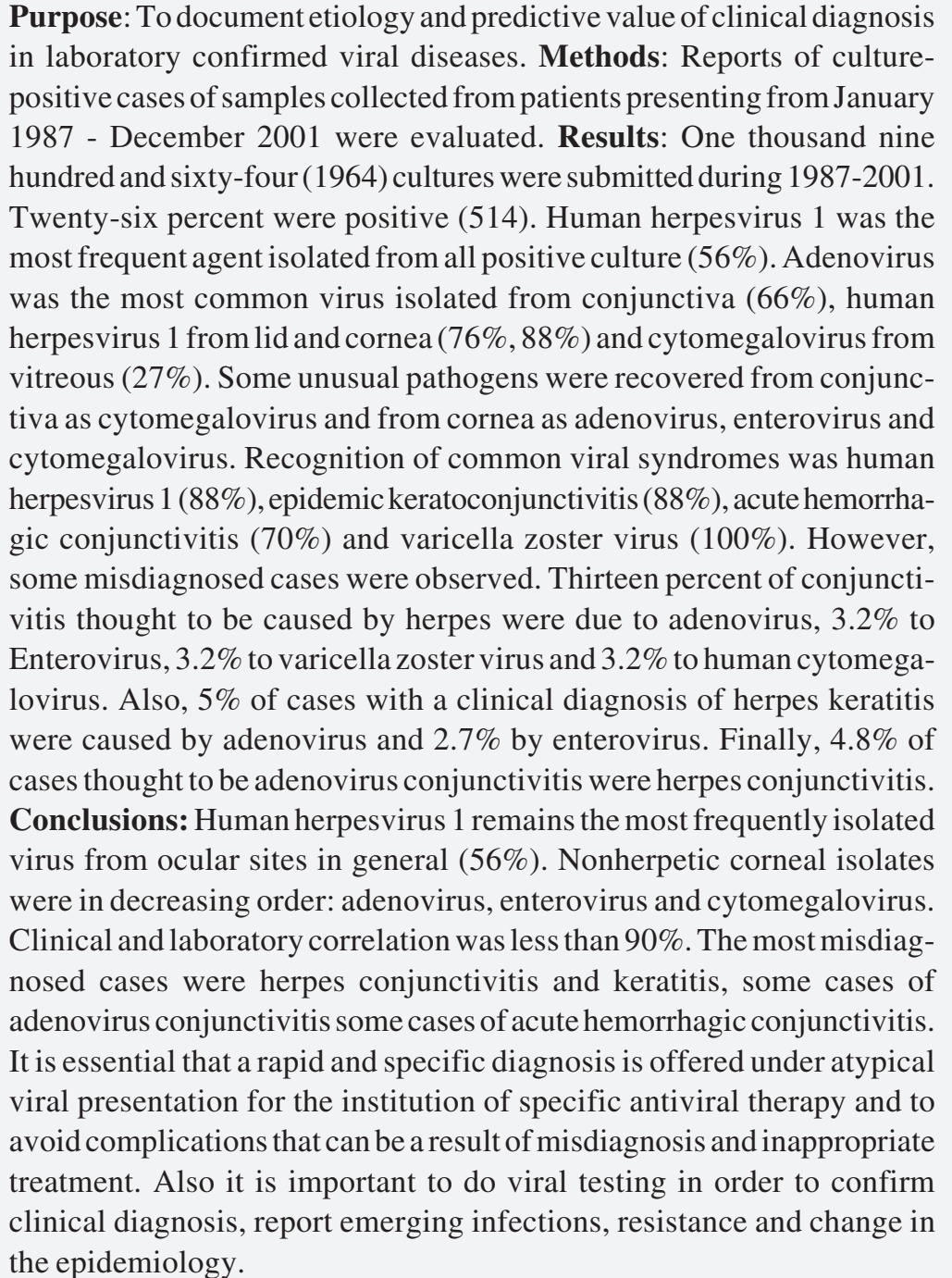 \\
\hline
\end{tabular}

Keywords: Eye infections, viral/diagnosis; Eye infections, viral/etiology; Keratitis, herpetic/ diagnosis; Simplexvirus/isolation \& purification; Polymerase chain reaction; Sensitivity and specificity 


\section{INTRODUCTION}

The eye and its adnexal structures are subject to a great number of diseases that are attributable to viruses such as herpes simplex 1, 2 (HSV 1, 2), varicella zoster virus (VZV), adenovirus, enterovirus, cytomegalovirus (CMV), EpsteinBarr virus, rabies virus, measles, mumps and others ${ }^{(1)}$.

Viruses can affect many different areas of the eye from lid, skin, conjunctiva and cornea to retina, choroid and optic nerve. There are multiple ocular manifestations of viral infection from mild conjunctivitis with minimal sequelae to the severe and blinding infections caused by HSV and VZV such as progressive outer retinal necrosis $(\mathrm{PORN})^{(1)}$.

HSV is the virus most commonly detected in most diagnostic laboratories ${ }^{(2)}$. There are approximately 20,000 new cases of ocular HSV in the United States per year and more than 28,000 reactivations annually ${ }^{(3)}$. HSV epidemiology has been changing. HSV 1 infection is being acquired for the first time in older age group and is an increasing cause of genital infections ${ }^{(4-5)}$.

HSV most commonly affects the cornea producing keratitis that can be recurrent and may lead to corneal vascularization. Uncommon cases of HSV ocular infection presenting as acute follicular conjunctivitis are difficult to differentiate from other causes, such as adenovirus ${ }^{(6)}$.

Adenovirus and enterovirus may cause a dendritic keratitis almost indistinguishable from infections initiated by HSV 1 / HSV $2^{(7)}$.

Human cytomegalovirus (CMV) is an unusual cause of systemic and ocular diseases in immunocompetent individuals, however it is frequent in immunocompromised patients ${ }^{(8)}$. There has been a significant increase in the incidence of CMV retinitis since the beginning of the AIDS epidemic. CMV retinitis is seen in $25 \%-40 \%$ of patients with Acquired Immunodeficiency Syndrome (AIDS) ${ }^{(8)}$. Anterior segment manifestations of CMV are rarely recognized, however bilateral CMV keratitis in a patient with AIDS has been described ${ }^{(9)}$.

Although the diagnosis of viral eye disease is usually clinical, newer techniques, such as polymerase chain reaction (PCR), have expanded the tools available to elucidate etiology in cases with unusual presentation ${ }^{(1)}$. Multiple methods are used for the laboratory diagnosis of viral infections, including viral culture, antigen detection, nucleic acid detection, and serology.

Documentation of early emerging trends is important in order to properly manage patients, educate, and alert health care professionals.

In this study we document etiology and predictive value of clinical diagnosis in laboratory confirmed viral diseases.

\section{METHODS}

Reports for all virus culture-positive cases from samples collected from patients presenting from January 1987 - December 2001 at the Bascom Palmer Eye Institute were evaluated.
Corneal, conjunctival scrapings and intraocular fluids were inoculated into conventional cell lines (Bartels, Inc, ViroMed, Inc) in accordance with requested virus. HSV: MRC-5, A549; adenovirus: MRC-5, A549; VZV: MRC-5, A549, HF, LLCMK2; CMV: HF, MRC-5; enterovirus: MRC-5, A549, LLCMK2 or PMK, HF. Intraocular fluids and tissues were inoculated into 2 MRC-5s, $1 \mathrm{HF}, 1$ LLC-MK2 or PMK. Tubes were incubated in a $\mathrm{CO}_{2}$ tissue culture incubator and observed at least twice a week for the presence of cytopathic effect (CPE).

Monoclonal antibodies from Syva (HSV, CMV), Bartels (adenovirus, HSV), Meridian Diagnostics (VZV) and or Chemicon (enterovirus, adenovirus) were used to help confirm viral $\mathrm{CPE} /$ and or direct antigen detection (smears).

\section{RESULTS}

One thousand nine hundred and sixty-four (1964) cultures were submitted during 1987-2001. Twenty-six percent were positive (514). Lids and conjunctiva were the sources with the highest positive rates (48.7\% and 30.9\% respectively) (Figure 1).

HSV 1 was the most frequent agent isolated from all positive culture (56\%), followed by adenovirus (31\%) (Figure 2 ). No seasonal variation was observed for HSV. However, adenovi-

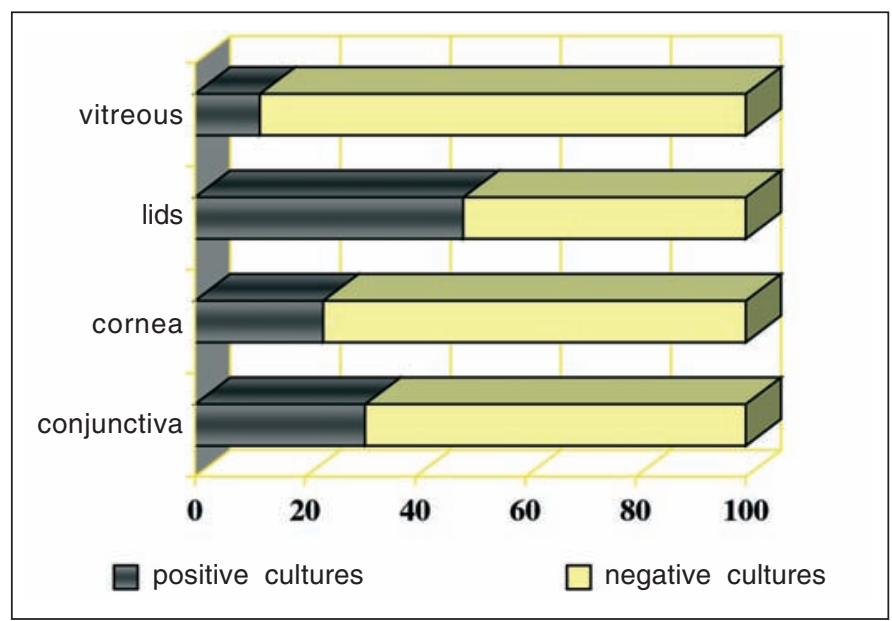

Figure 1 - Culture-positive rates by source

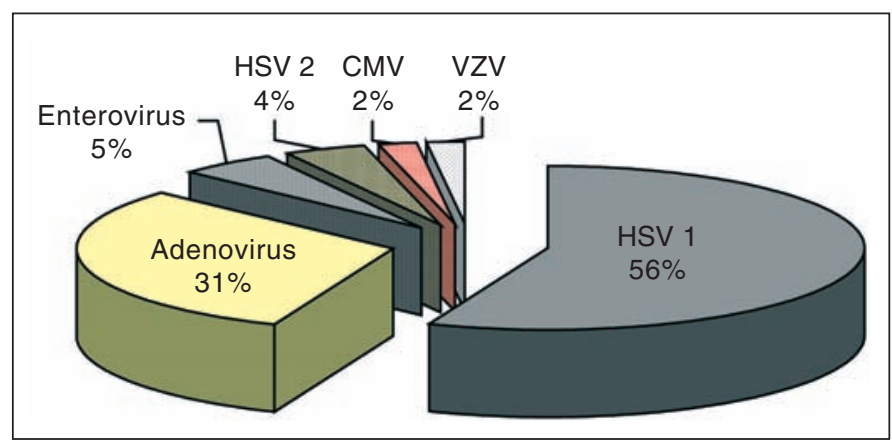

Figure 2 - Spectrum of viral isolates - BPEI 1987-2001 ( $\mathrm{N}=514)$ 
rus was more likely recovered during summer and fall. Enterovirus was more frequently seen during the fall as can be observed in Figure 3.

Average detection time ranged from less than or equal to 24 hours (HSV) to 30 days (CMV, adenovirus). HSV 1 and HSV 2 were the fastest isolates recovered from traditional cell cultures compared to the other virus. About $78 \%$ of HSV was recovered within 72 hours. Time to detection for other virus can be observed in Figure 4. The most sensitive cell lines were the A549 (97.2\%) and MRC5 (57.3\%).

Adenovirus was the most common virus isolated from conjunctiva (66\%), HSV 1 from lid and cornea $(76 \%, 88 \%)$ and CMV from vitreous (27\%) followed by enterovirus (22\%). Also 1 case of CMV from cornea was seen (Figure 5).

Clinical diagnosis correlated well with laboratory results. Recognition of common viral syndromes was HSV keratitis and conjunctivitis (88\%), EKC (88\%), acute hemorrhagic conjunctivitis (AHC) (70\%) and VZV keratitis, conjunctivitis and lid infection (100\%). However, some misdiagnoses were observed. Thirteen percent of conjunctivitis thought to be caused by herpes were due to adenovirus, $3.2 \%$ to enterovirus, $3.2 \%$ to VZV and 3.2\% to CMV. Also, $5 \%$ of cases with clinical diagnosis of herpes keratitis were caused by adenovirus and $2.7 \%$ by enterovirus. In addition, $4.8 \%$ of cases thought to be adenovirus conjunctivitis were herpes conjunctivitis. Finally $30 \%$ of the cases with clinical diagnosis of AHC were due to adenovirus (Table 1).

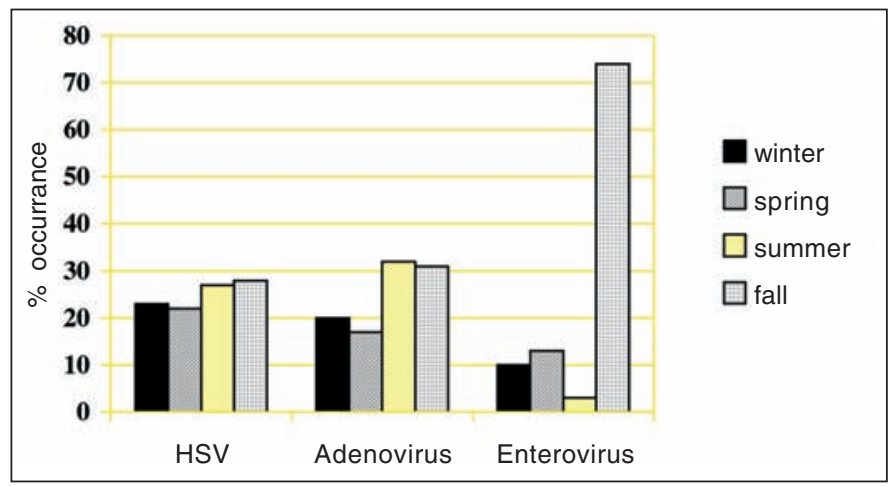

Figure 3 - Seasonality - viral isolate - BPEI 1987-2001

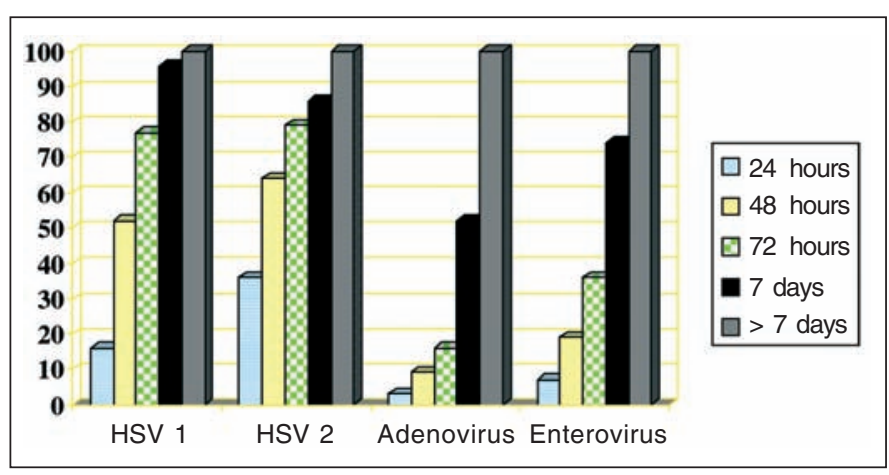

Figure 4 - Days to detection (Traditional cell culture)

\section{DISCUSSION}

Clinical and laboratory correlation was less than $90 \%$ in all major ocular viral diseases including HSV keratitis and conjunctivitis, EKC, AHC. Some other studies have shown an even lower correlation. Kowalsaki et al., found that only $65 \%$ (53/81) of patients with culture-positive disease were given a clinical diagnosis and treated for $\mathrm{HSV}$ at the initial clinical examination $^{(10)}$. Clinico-virological correlation studies in Chi$\mathrm{le}^{(11)}$ and India ${ }^{(12)}$ showed a $77 \%$ and $44 \%$ correlation in cases of herpes epithelial keratitis and $20 \%$ and $14.8 \%$ correlation in stromal keratitis, respectively.

History and physical examination are the best tools for diagnosing infectious diseases of the cornea and ocular adnexa, however laboratory studies can assist in the differential diagnosis of atypical viral presentations. In addition, early diagnosis of superficial viral infections is crucial for epidemiological and therapeutic reasons, allowing the appropriate treatment strategies to control the disease.

Recently, few studies about ocular virus surveillance are available. Some studies report the prevalence of a specific viral disease during a specific period of time. In general ophthalmologists treat viral diseases based only on clinical appearance,

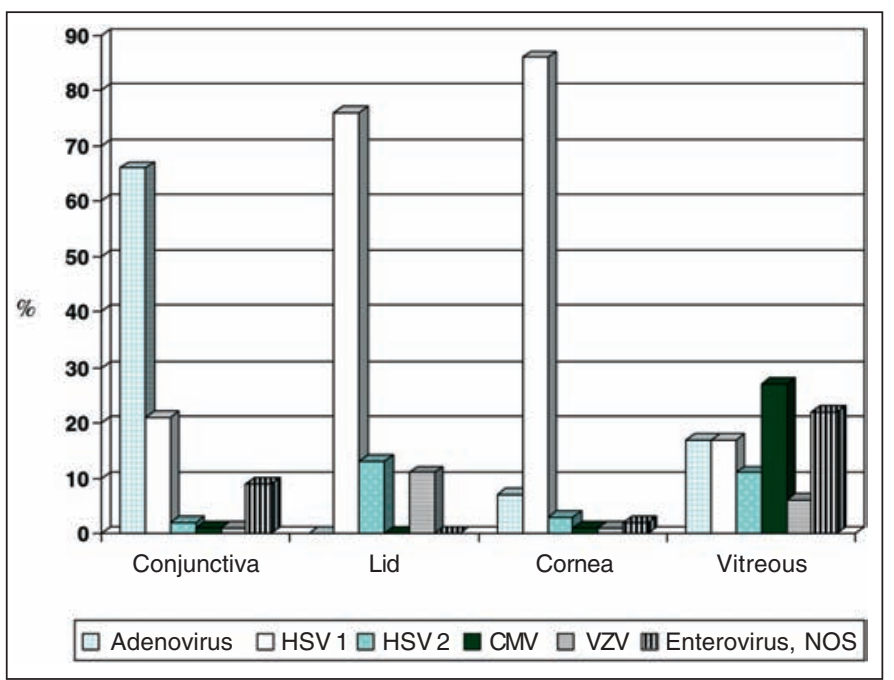

Figure 5 - Conjunctival, lid, corneal and vitreous viral isolates - BPEI 1987-2001

\begin{tabular}{|c|c|c|c|c|c|}
\hline \multirow{2}{*}{$\begin{array}{l}\text { Clinical } \\
\text { diagnosis }\end{array}$} & \multicolumn{5}{|c|}{ Laboratory results } \\
\hline & adeno & entero & VZV & CMV & herpes \\
\hline Herpes conj & $13 \%$ & $3.2 \%$ & $3.2 \%$ & $3.2 \%$ & \\
\hline Adeno conj & & & & & $4.8 \%$ \\
\hline $\mathrm{AHC}$ & $30 \%$ & & & & \\
\hline Herpes keratitis & $5 \%$ & $2.7 \%$ & & & \\
\hline
\end{tabular}


therefore we might not know the true prevalence of all ocular viral diseases. We thought it would be valuable to report the etiology of laboratory-confirmed viral diseases and predict the value of clinical diagnosis.

HSV 1 remains the most frequently isolated virus from ocular sites in general (56\%). Typically, ocular disease is caused by herpes type 1 however, $3 \%$ of corneal viral isolates in our study were due to HSV 2. It has been suggested that ocular HSV type 2 infections may have a less favorable outcome ${ }^{(13)}$, so maybe it would be interesting to know the type of HSV in ocular infection. There are no recent studies concerning the incidence of ocular infection by HSV 1 versus HSV $2^{(14)}$. The first study suggesting transmission of HSV 2 from the genital site to the eye was published by $\mathrm{Oh}$ in $1976^{(15)}$. The author reported 2 cases of blepharoconjunctivitis and 1 case of keratoconjunctivitis in 2 adults with prior history of genital disease and 1 child with close contact with her sister who apparently had genital disease. In 1978, Neumann-Haefelin found in a continuous series of 457 patients that 154 had HSV 1 and 3 had HSV $2(1.9 \%)$ when isolating and typing virus ${ }^{(13)}$. There is one report of simultaneous HSV 1 and 2 infecting a cornea in a patient with AIDS $^{(16)}$. Recently, Inoda reported a case of stromal keratitis and anterior uveitis due to herpes simplex virus type 2 in a young child ${ }^{(17)}$. The higher prevalence of HSV 2 in ocular disease found in our study might be a consequence of the increased incidence of genital HSV in the United States ${ }^{(13)}$. This change in the epidemiology supports the importance of laboratory diagnosis in viral diseases. It is also fundamental in order to confirm resistance to antivirals. Some cases of herpes keratitis resistant to acyclovir have already been published ${ }^{(18-19)}$ and some studies have shown that type $2 \mathrm{HSV}$ isolates have higher ID 50 (50\% of inhibitory dose) values than type 1 when tested for acyclovir sensitivity $^{(20)}$.

Seasonal patterns depend on viral serotypes, population groups and type of exposure. HSV virus was detected during all seasons. This is in accordance with some authors who also found no seasonal peak for HSV ocular infection ${ }^{(21-22)}$. In contrast, some other studies reviewed the seasonality of ocular $\mathrm{HSV}$ and found a more frequent occurrence during the winter months ${ }^{(23-25)}$.

Adenovirus was more common during summer and fall. In Japan, adenovirus was also detected most frequently in the Summer ${ }^{(22,26)}$.

Seven percent of corneal keratitis cases were due to adenovirus. So, it is not always herpes. This prevalence is a little higher than the one found in the literature ${ }^{(7)}$. The medical records of patients with a corneal positive culture specimen for adenovirus from 1986 to 1992 at Bascom Palmer Eye Institute were reviewed. Adenovirus represented $5 \%$ of all positive viral corneal cultures at that time. Also, the authors concluded that adenovirus-associated epithelial keratitis rarely can mimic infection of corneal epithelium by HSV and that adenoviruses do infect human corneal epithelium. Adenovirus and enterovirus isolates may play an increasing role in nonherpetic disease of the cornea and intraocular tissues. In addition, with the help of the laboratory results, we were able to identify one case of VZV and one case of CMV from cornea.

Twenty-six percent of all submitted virus cultures were positive. This low prevalence of positivity maybe is related to quality of sample, specimen handling in viral transport media, prior treatment, requirement of viable viral particles to confirm the characteristic cytopathic effect and misdiagnosis. In general, the isolation rates of $\mathrm{HSV}-1$ in cultures from corneal specimens have been low, irrespective of the used cell line ${ }^{(27)}$. For example, it was found that only $22.4 \%(\mathrm{~N}=161)$ of all cornea scrapings of clinically suspected HSK subjected to culture were positive $^{(12)}$ and a positive rate of $32.4 \%(\mathrm{~N}=74)$ of all cases suspected to be HSK using tube cultures (Vero cell line) was described ${ }^{(28)}$.

In our laboratory, human lung carcinoma (A549) and human lung diploid fibroblast (MRC5) were the most sensitive cell lines. However, some authors suggest that Vero cells line perform better in the isolation of HSV $1^{(29)}$. We particularly do not have experience with Vero cell line. In general, A549 and MRC5 have been our choices due to their ability of recovering adenovirus, HSV and CMV and to their high sensitivity observed in our laboratory for the last years.

The most misdiagnosed cases were herpes conjunctivitis and keratitis when in fact they were caused by adenovirus and some cases of adenovirus conjunctivitis that actually were caused by herpes.

Five cases $(5 / 103,4.8 \%)$ of cases thought to be adenovirus conjunctivitis were herpes conjunctivitis. This incidence is similar to the one found by Uchio when studying clinical and epidemiological features of acute follicular conjunctivitis $(4.3 \%)^{(6)}$. It has also been reported that the incidence of HSV ocular infection presenting as acute follicular conjunctivits in the absence of corneal or lid signs in cases of clinically diagnosed EKC is $1.4-7 \%^{(30-32)}$. It is clinically difficult to distinguish HSV conjunctivitis from adenoviral conjunctivitis in the acute stage, since the clinical features of adenoviral conjunctivitis are similar to those of HSV conjunctivitis ${ }^{(29)}$.

In summary, the clinical and laboratory correlation was less than $90 \%$. It is essential that a rapid and specific diagnosis is offered under atypical viral presentation for the institution of specific antiviral therapy and to avoid complications that can be a result of misdiagnosis and inappropriate treatment. It is also important to do viral testing in order to confirm clinical diagnosis, report emerging infections, resistance and change in the epidemiology.

\section{CONCLUSIONS}

HSV 1 remains the most frequently isolated virus from ocular sites in general (56\%). Nonherpetic corneal isolates were in decreasing order: adenovirus, enterovirus and CMV. Clinical and laboratory correlation was less than $90 \%$. The most misdiagnosed cases were herpes conjunctivitis and keratitis, some cases of adenovirus conjunctivitis, some cases 
of AHC. It is essential that a rapid and specific diagnosis is offered under atypical viral presentation for the institution of specific antiviral therapy and to avoid complications that can be a result of misdiagnosis and inappropriate treatment.

\section{RESUMO}

Objetivos: Documentar a etiologia e prever a importância do diagnóstico clínico em doenças virais oculares confirmadas em laboratório. Métodos: Todos os relatórios de pacientes com cultura viral positiva durante o período de janeiro 1987 dezembro 2001 foram analisados. Resultados: Quinhentos e quatorze (514) casos foram encontrados. Em geral, herpesvírus 1 humano foi o agente mais freqüentemente isolado. Adenovírus foi o vírus mais comumente isolado da conjuntiva (66\%), herpesvírus 1 humano das pálpebras e córnea $(76 \%$, $88 \%$ respectivamente) e citomegalovírus do vítreo (27\%). Alguns agentes não usuais foram isolados da conjuntiva como citomegalovírus e da córnea como adenovírus, enterovírus e citomegalovírus. Reconhecimento das síndromes virais comuns foi: herpervírus 1 humano (88\%), ceratoconjuntivite epidêmica (88\%), conjuntivite aguda hemorrágica (70\%). Porém, alguns casos com diagnóstico incorreto foram observados. Treze por cento das conjuntivites com diagnóstico de herpes foram causadas por adenovírus, 3,2\% por enterovírus, $3,2 \%$ por varicella zoster vírus e $3,2 \%$ por citomegalovírus. Também, 5\% dos casos com diagnóstico clínico de ceratite herpética eram adenovírus e 2,7\% enterovírus. Além disso, $4,8 \%$ dos casos em que se pensaram em conjuntivite por adenovírus, eram conjuntivite por herpes. Finalmente, 30\% dos casos em que se diagnosticaram conjuntive hemorrágica aguda, o agente etiológico era adenovírus. Conclusão: Em geral herpesvírus humano 1 continua a ser o vírus mais comum encontrado nas infecções oculares (56\%). Agentes não herpéticos isolados da córnea foram em ordem decrescente: adenovírus, enterovírus e citomegalovírus. A correlação entre o diagnóstico clínico e laboratorial foi menor do que $90 \%$. Um diagnóstico rápido e específico é essencial em casos de apresentações virais atípicas para que uma terapia antiviral específica seja estabelecida e para se evitar complicações que podem ser decorrentes de um diagnóstico errado e tratamento inadequado. Teste viral também é importante para se confirmar um diagnóstico clínico, relatar infecções emergentes e mudanças de epidemiologia.

Descritores: Infecções oculares virais/diagnóstico; Infecções oculares virais/etiologia; Ceratite herpética/diagnóstico; Simplesvírus/isolamento \& purificação; Reação em cadeia da polimerase; Sensibilidade e especificidade

\section{REFERENCES}

1. Ritterband DC, Friedberg DN. Virus infections of the eye. Rev Med Virol. 1998;8(4):187-201.
2. Smith TF, Wold AD, Espy MJ, Marshall WF. New developments in the diagnosis of viral diseases. Infect Dis Clin North Am. 1993,7(2):183-201.

3. Liesegang TJ, Milton LJ 3rd, Daly PJ, Ilstrup DM. Epidemiology of ocular herpes simplex. Incidence in Rochester, Minn, 1950 through 1982. Arch Ophthalmol. 1989;107(8):1155-9.

4. Lavery HA, Connolly JH, Russel JD. Incidence of herpes genitalis in Northern Ireland in 1973-83 and herpes simplex types 1 and 2 isolated in 1982-4. Genitourin Med. 1986;62(1):24-7.

5. Ross JD, Smith IW, Elton RA. The epidemiology of herpes simplex types 1 and 2 infection of the genital tract in Edinburg 1978-1991. Genitourin Med. 1993;69(5):381-3.

6. Uchio E, Takeuchi S, Itoh N, Matsuura N, Ohno S, Aoki K. Clinical and epidemiological features of acute follicular conjunctivitis with special reference to that caused by herpes simplex virus type 1. Br J Ophthalmol. 2000;84(9): 968-72.

7. Chodosh J, Miller D, Stroop WG, Pflugfelder SC. Adenovirus epithelial keratitis. Cornea. 1995;14(2):167-74.

8. Kuppermann BD, Petty JG, Richman DD, Mathews WC, Fullerton SC, Richman DD, et al. Correlation between CD4+ counts and prevalence of cytomegalovirus retinitis and human immunodeficiency virus-related noninfectious retinal vasculopathy in patients with acquired immunodeficiency syndrome. Am J Ophthalmol. 1993;115(5):575-82.

9. Wilhelmus KR, Font RL, Lehmann RP, Cernoch PL. Cytomegalovirus keratitis in acquired immunodeficiency syndrome. Arch Ophthalmol. 1996;114(7): 869-72.

10. Kowalski RP, Gordon YJ, Romanowski EG, Araullo-Cruz T, Kinchington PR. A comparison of enzyme immunoassay and polymerase chain reaction with the clinical examination for diagnosing ocular herpetic disease. Ophthalmology. 1993;100(4):530-3.

11. Martinez MN, Vogel M, Stoppel J, Charlin R, Squella O, Srur M, et al. Herpetic keratitis: clinico-virological correlation. Rev Med Chil. 1997;125(6):659-64.

12. Pramod NP, Rajendran P, Kannan KA, Thyagarajan SP. Herpes simplex keratitis in South India: clinico-virological correlation. Jpn J Ophthalmol. 1999;43(4):303-7.

13. Neumann-Haefelin D, Sundmacher R, Wochnik G, Bablok B. Herpes simplex virus types 1 and 2 in ocular disease. Arch Ophthalmol. 1978;96(1):64-9.

14. Liesagang TJ. Herpes simplex virus epidemiology and ocular importance. Cornea. 2001;20(1):1-13.

15. Oh JO, Kimura SJ, Ostler HB, Dawson CR, Smolin G. Oculogenital transmission of type 2 herpes simplex virus in adults. Surv Ophthalmol. 1976;21 (2):106-9.

16. Rosenwasser GO, Greene WH. Simultaneous herpes simplex types 1 and 2 keratits in acquired immunodeficiency syndrome. Arch Ophthalmol. 1992;113 (1):102-3.

17. Inoda S, Wakakura M, Hirata J, Nakazato N, Toyo-Oka Y. Stromal keratitis and anterior uveitis due to herpes simplex virus-2 in a young child. Jpn J Ophthalmol. 2001;45(6):618-21.

18. Bodaghi B, Mougin C, Michelson S, Agut H, Dighiero P, Offret H, et al Acyclovir-resistant bilateral keratitis associated with mutations in the HSV-1 thymidine kinase gene. Exp Eye Res. 2000;71(4):353-9.

19. Pramond NP, Thyagarajan SP, Anandakannam K. Acyclovir resistance in herpes simplex virus isolates from keratitis cases: an analysis from a developing country. Microbiol Immunol. 2000;44(4):241-7.

20. Crumpacker C. Resistance of herpes simplex virus to anti-viral agents. Is it clinically important? Drugs. 1983;26(5):373-7.

21. Liesegang TJ, Melton LJd, Daly PJ, Ilstrup DM. Epidemiology of ocular herpes simplex. Incidence in Rochester, Minn, 1950 through 1982. Arch Ophthalmol. 1989;107(8):1155-9.

22. Saitoh-Inagawa W, Aoki K, Uchio E, Itoh N, Ohno S. Ten years'surveillance of viral conjunctivitis in Sapporo, Japan. Graefes Arch Clin Exp Ophthalmol. 1999;237(1):35-8.

23. Bell DM, Holman RC, Pavan-Langston D. Herpes simplex keratis: epidemiologic aspects. Ann Ophthalmol. 1982;14(5):421-2,424.

24. Liesegang TJ. Epidemiology of ocular herpes simplex. Natural history in Rochester, Minn, 1950 through 1982. Arch Ophthalmol. 1989;107(8):1160-5.

25. Uchio E, Hatano H, Mitsui K, Sugita M, Okada K, Goto K, et al. A retrospective study of herpes simplex keratitis over the last 30 years. Jpn J Ophthalmol. 1994;38(2):196-201.

26. Aoki K, Tagawa Y. A twenty-one year surveillance of adenoviral conjunctivitis in Sapporo, Japan. Int Ophthalmol Clin. 2002;42(1):49-54.

27. Kaye SB, Baker K, Bonshek K, Maseruka H, Grinfeld E, Tullo A, et al. Human herpes viruses in the cornea. Br J Ophthalmol. 2000,84(6):563-71. 
28. Athmanathan S, Bandlapally S, Rao GN. Comparison of the sensitivity of a 24h-shell vial assay, and conventional tube culture, in the isolation of Herpes simplex virus-1 from corneal scrapings. BMC Clin Pathol. 2002;2(1):1.

29. Athmanathan S, Reddy SB, Nutheti R, Raro GN. Comparison of an immortalized human corneal epithelial cell line with vero cells in the isolation of Herpes simplex virus 1 for the laboratory diagnosis of Herpes simplex keratitis. BMC Ophthalmology. 2002;2(1):3.

30. Aoki K, Kawana R, Matsumoto I, Wadell G, De Jong JC. Viral conjunctivi- tis with special reference to adenovirus type 37 and enterovirus 70 infection. Jpn J Ophthalmol. 1986;30(2):158-64.

31. Harding SP, Mallinson H, Smith JL, Clearkin LG. Adult follicular conjunctivitis and neonatal ophthalmia in a Liverpool eye hospital, 1980-1984. Eye. 1987;1(Pt 4):512-21.

32. Daurogar S, Wishhart MJ, Viswalingam ND. Epidemiological and clinical feature of primary herpes virus ocular infection. Br J Ophthalmol. 1985;69 (1):2-6.

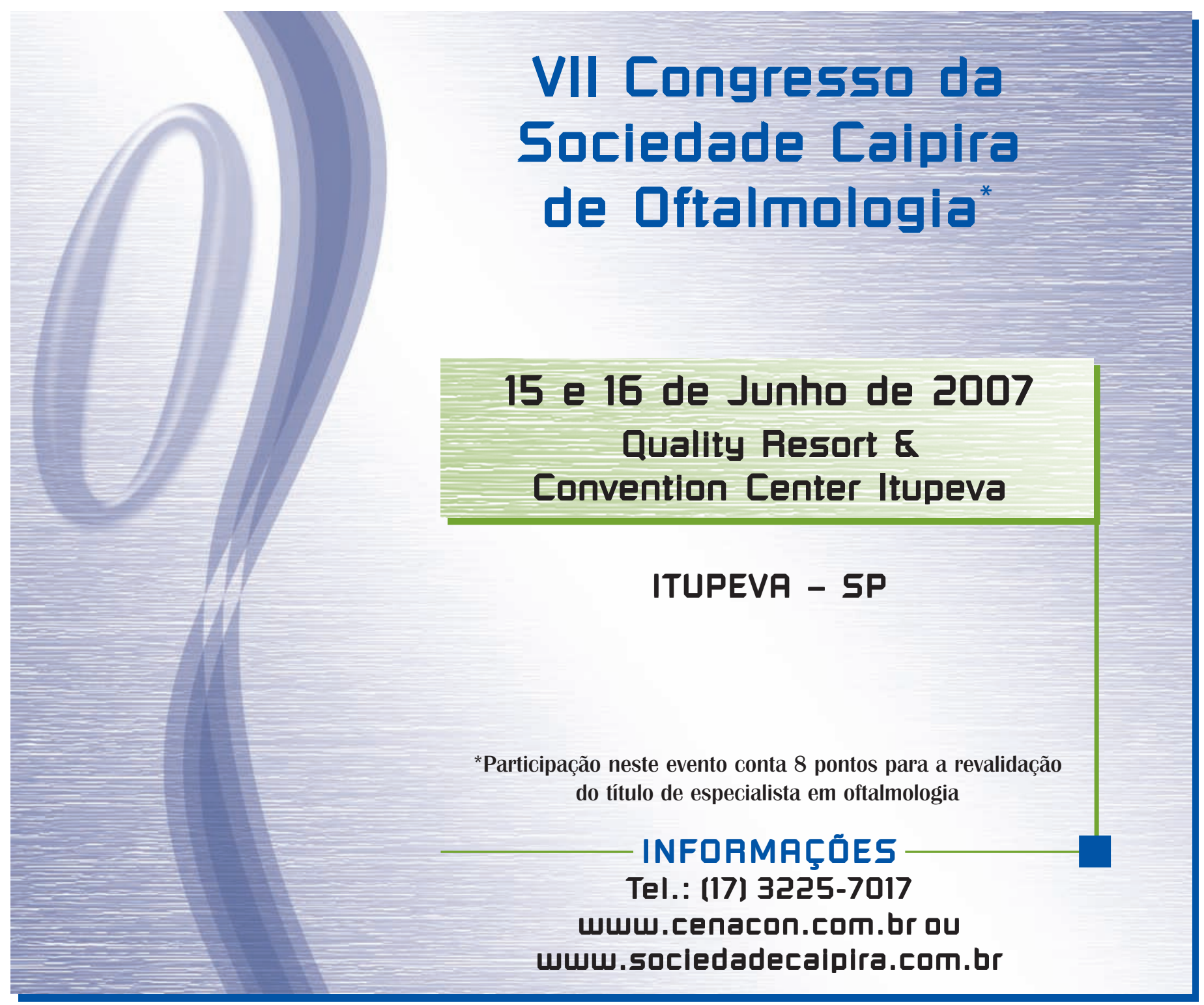

